\title{
Fibroblast Growth Factor 2
}

National Cancer Institute

\section{Source}

National Cancer Institute. Fibroblast Growth Factor 2. NCI Thesaurus. Code C20547.

Fibroblast growth factor 2 (288 aa, $\sim 31 \mathrm{kDa}$ ) is encoded by the human FGF2 gene. This protein plays a role in the regulation of cell proliferation, angiogenesis, and limb and nervous system development. 